\title{
7 \\ Margaret Cavendish and Thomas Hobbes on Freedom, Education, and Women
}

\author{
Karen Detlefsen
}

Thomas Hobbes exerted one of the most significant contemporary influences on the thought of Margaret Cavendish. Hobbes's influence was both positive and negative. Cavendish shares many important doctrines with him, some of which put them in a very small minority in the seventeenth century. Both are materialists with respect to the natural world. ${ }^{1}$

I am grateful for criticisms and suggestions from audience members at the Works in Progress Seminar (Alice Paul Center for Research on Women, Gender, and Sexuality, University of Pennsylvania, 2011); Women, Philosophy, and History: A Conference in Celebration of Eileen O'Neill and Her Work (Barnard College, 2009); and the Philadelphia Political Theory Workshop (Political Science, University of Pennsylvania, 2007). Many thanks for helpful comments from two anonymous referees of this book. I owe an enormous debt of gratitude to Nancy Hirschmann and Joanne Wright for insightful comments and help at many stages of writing this chapter. 
Both explicitly distinguish between the sphere of inquiry concerned with the natural and human (moral and civic) world on the one hand, and the sphere of inquiry concerned with God on the other hand. ${ }^{2}$ Both take the maintenance of peace and stability, and concomitantly the avoidance of civil war, to be the primary civic goal, and both assert that a government based in absolute sovereignty is required to achieve the maintenance of peace. But to a significant degree, Cavendish's own philosophy emerges from her rejection of various doctrines of a number of her contemporaries, and Hobbes is among her principal targets. In this chapter, I focus on their divergent accounts of freedom, the social conditions in which freedom can be exercised, and the role of education and welldeveloped rationality in the exercise of freedom, to show that Cavendish provides a view of women's freedom that escapes some of the less advantageous aspects of Hobbes's own view.

\section{Cavendish on Women, Education, and Freedom}

In her nonfiction work, Cavendish notes with regularity that her own lack of superior education is the source of her own intellectual limitation, and she extends this to women in general. ${ }^{3}$ But the point emerges even more forcefully and fully in her fictional work, specifically in many of her plays, where she also connects education and reason with freedom. Indeed, given that she explicitly (even if disingenuously) claims in her theoretical works to avoid political topics since they are the proper province of men, not women, ${ }^{4}$ it is paramount that we look at her fiction, for it is there that we often see her delving extensively into precisely these sorts of topics, including what sort of society will best enable women's freedom. Here, I will focus on three of her plays as especially important to her theory of education and education's relation to women's freedom. These are Youths Glory, and Deaths Banquet (hereafter Youths Glory), The Female Academy, and The Convent of Pleasure.

There are two loosely related plot lines in Youths Glory. The one relevant for my concerns runs roughly as follows. Lady Sanspareille, daughter to Mother and Father Love, wants to pursue a life of education and oration and believes that she must forego marriage and having children in order to satisfy her life goals. Her mother would rather she pursue a more traditional female education, marry, and have children. Father Love encourages his daughter's choices and aids her in realizing her ambitions. 
Lady Sanspareille gains a superior education, becomes a well-regarded orator-the only female among many wise men-but tragically dies young after contracting a terrible disease. In The Female Academy, a number of women have retreated to a women-only educational institution under the tutelage of an older matron. There, they converse among themselves "wittily and rationally," with men outside the walls furious at their unwillingness to make themselves available for marriage and procreation. The women's seclusion is not complete, however, for there is a large open grate where the women and men are able to converse. Eventually, the men contact the matron and help convert her from leader of women into marriage broker, and the women inside the gates are married off to the men after the matron rewrites the academy's purpose as that of teaching women to be better wives. In The Convent of Pleasure, Lady Happy is the mentor of a group of women enclosed in a women-only educational institution, this one with no opening to the outside world; the men outside contemplate removing bricks in order to see what goes on within. ${ }^{6}$ Partway through the play, a princess arrives at the convent, and she and Lady Happy fall in love. Lady Happy openly contemplates pursuing what feels fully right and good to her-a lesbian relationship. In the end, the princess's identity is exposed; "she" is a prince, and the two enter into a heterosexual marriage.

Together, these plays present a strong voice in favor of a feminist line of argument. This argument pushes the conclusion that any actual connection found between sex and degree of intellect is the result of socialization and is therefore arbitrary and not natural. The cure for women's actual lesser degree of intellectual development is allowing women superior education typically afforded men alone. With such an education, women will find themselves freer both because they will have increased ability to pursue interesting projects and because they will have a wider range of projects to choose from. And given the realties of women's true social conditions, the way to attain such education and life chances is often through separation from debilitating social conditions such as having children, marrying men, and even being among men. This last point indicates a sensitivity to how relations enable or disable the development of capacities required for increased freedom, including a sensitivity to the power of women-only communities to enable women and to the fact that men have, in actual fact, often held women in relations that are disenabling. At the same time, Cavendish (herself the beneficiary of productive relations with men such as her husband, William, and brother-in-law, 
Charles) recognizes that men (e.g., Father Love) can be the source of very productive relations for women, just as women (e.g., Mother Love) can be the source of detrimental relations for other women. This only serves to underscore the general gist of these three plays: if people are equal regardless of their gender, then a woman socialized according to unhelpful gender norms (Mother Love) would be less likely to recognize her daughter's equality with men than would a man (Father Love) who was socialized differently.

The idea that any connection between sex and intellect is conventional and not natural is voiced most clearly in Youths Glory. It is true that Mother Love thinks a male style of education for her daughter would "change a womans nature and disposition" (Playes, 124; emphasis added). But the more strongly developed argument-as opposed to assertioncomes from Father Love: "Let me tell you, Wife, that is the reason all women are fools; for women breeding up women, one fool breeding up another, and as long as that custom lasts there is no hope of amendment, and ancient customs being a second nature, makes folly hereditary in that Sex, by reason their education is effeminate, and their times spent in pins, points and laces, their study only vain fashions, which breeds prodigality, pride and envie" (123-24; emphasis added). Father Love's argument that custom shapes what women are, including the custom of women educating one another in nonintellectual pursuits of vanity, is joined by the strongest argument in favor of dissociating sex and intellect, namely, the fact that Lady Sanspareille decides to become a philosopher and orator-educator, gains the requisite education, and actually becomes highly respected for her intellect. She, like her father, believes that there is no natural connection between lack of intellect and sex, expressing surprise at the other opinion: "as if it were ... against nature, for Women to have wit" (131). Mother Love's claim that a man's education would change her daughter's nature indicates that she, too, must take such a "nature" to be malleable and thus nonessential to women, even if she does not see this.

All three plays point to the necessity of good education for women as a crucial social change that will help develop women's intellectual abilities. "Good" education is not the rearing of girls to be concerned with fashion, nor is it (as Father Love emphasizes) the rearing of girls in less favorable forms of education often pursued by men who are "bred up to swear, swagger, gaming, drinking, Whoring" (Playes, 124). Good education for both women and men is education in the sciences, literature, and music 
(123-24), a point echoed in The Female Academy, in which the matron educates the young women to be able to rationally discuss the nature of wisdom, truth, rhetoric, and friendship (passim).

Cavendish also connects increased intellectual ability through greater access to good education with women's increased freedom. Again, Father Love's arguments posed against Mother Love's beliefs spell this out clearly. Mother Love's fear is that the education envisioned for Lady Sanspareille by her father will "give her no time for recreation, nor no liberty for company, nor freedom for conversation, but keeps her as a Prisoner, and makes her a slave to her book" (Playes, 123; emphasis added). Father Love counters by asking rhetorically, "Can she have freer conversation, than with wit ... ?" (123; emphasis added), thus indicating the freeing power of a developed intellect. Once again, Lady Sanspareille's choosing to live out such a life, and making herself into the person she envisions, speaks volumes for Cavendish's own recognition of (and quite possibly approval of) the increase of women's power and therefore freedom through education. Indeed, it is a position echoed by Lady Happy in The Convent of Pleasure: "My Cloister shall not be a Cloister of restraint, but a place for freedom" (Convent, 220).

Cavendish shows herself to be amply aware of how relations can both enable and constrain an individual's abilities and freedom, and she shows herself to be attune to the actual social fact that women have been routinely constrained by their relations with men, while men have been routinely unable to acknowledge the subjectivity of women. She furthermore demonstrates that she is alert to the possibilities for women (and threats to men) should women place themselves in more equitable, caring relations. The strong message found in all three plays is that such relations cannot come from most men as they have been socialized (again with notable exceptions such as Father Love) - neither intimate relations such as marriage, nor relations in broader communities-but they can often better come from women pursuing the individual, single life with the help of caring individuals, or from women cloistering themselves in female-only, closed communities. Thus, we find Lady Sanspareille eschewing marriage: "If I marry, although I should have time for my thoughts and contemplations, yet perchance my Husband will not approve of my works. ... I am of opinion, that some men are so inconsiderately wise, gravely foolish and lowly base, as they had rather be thought Cuckolds, than their wives be thought wits, for fear the world should think their wives the wiser of the two" (Playes, 131). The theme of the 
marital relation often being a harmful one for women is echoed in The Convent of Pleasure when, for example, the women of the convent perform masques in which there are fully ten scenes depicting women suffering in various ways in the marital bond. It is no wonder that Lady Happy believes that the "best of men, if any best there be ... [brings] more crosses and sorrows than pleasure, freedom or happiness," and that men "make the Female sex their slaves" (Convent, 218 and 220). An obvious solution to this problem-one presented in both The Female Academy and The Convent of Pleasure-is for women to provide themselves with the sorts of communities that offer healthy relations that enable women, develop their intellects, and thus make them more free. Not only will women in such circumstances find themselves with a greater measure of agency, but they will also find themselves able to take on a range of occupations not available to them in communities where men monopolize certain professions. In the convent, for example, there will be "Women-Physicians, Surgeons, and Apothecaries" (Convent, 223).

Even the apparently equivocal messages in each of the plays that seem to circumvent their feminist promise are either innocuous or actually underscore the feminist message. For the failure of the women to fully realize their freedom through great education is due in one case to natural causes (disease) and, tellingly, in the other two cases, to the intrusion into productive female communities by men who wish to dismantle those communities. That is, in the latter two cases, deleterious social relations thwart the women. Finally, Cavendish makes clever-and subversiveuse of a convent, typically a place where women can enjoy the female pleasures of life, ${ }^{7}$ for not only does she use a large portion of this play to present the dangers of marriage for women, but she also notes that in such a setting, women will need to take on pursuits that require considerable intellectual engagement, such as doctoring.

Cavendish, writing the century before Mary Wollstonecraft, already presents in these three plays the then-radical view that women are entitled to the same first-rate education and consequent careers as men, and in two of these plays, she champions the yet more radical view of singlesex education as the best way to realize women's full potential. This alone proposes a feminist alternative to any vision of women and education we see in Hobbes, but when we turn to the theory that grounds Cavendish's approach in her drama, her striking feminist alternative to Hobbes emerges with full force. 
Human Nature, Civil Society, and Freedom

To understand the theoretical grounding of Cavendish's theory of women's freedom, it is helpful to explicate a few features of her theory of individuals, including human individuals. In her Philosophical Letters, she takes issue with what she sees as Hobbes's view of freedom, according to which the human will is not free. According to Hobbes, the will is assimilated to fully determined appetites-" "the will is appetite; [man can no more] determine his will than any other appetite, that is, more than he can determine when he will be hungry and when not"s - and the will is simply the last appetite before action. It is thus a contradiction to speak of a "free will," even while it makes perfect sense to speak of a free human (Leviathan, ch. 21, 262). Deliberation is the alternating of desires (or appetites and aversions, including emotions such as hope and fear) to either perform or not perform a given action, before the final appetite (will) determines an action (ch. 6, 127). Similarly, human action is necessitated because human action follows from a necessitated human will. As a result, Hobbes must define liberty or freedom in such a way that it is consistent with necessity:

Liberty and Necessity are Consistent ... in the Actions which men voluntarily doe; which (because they proceed from their will) proceed from liberty; and yet because every act of mans will, and every desire, and inclination proceedeth from some cause, and that from another cause, which causes in a continuall chaine (whose first link in the hand of God the first of all causes) proceed from necessity. So that to him that could see the connexion of those causes, the necessity of all mens voluntary actions, would appeare manifest. (ch. 21, 263)

In contrast, Cavendish disputes Hobbes's claim that voluntary motions "depend upon a precedent thought": "It doth imply a contradiction, to call them Voluntary Motions, and yet to say they are caused and depend upon our Imagination. . . . How can they be voluntary motions, being in a manner forced and necessitated to move according to Fancy or Imagination?" (Philosophical Letters, 45-46). ${ }^{9}$ Cavendish disagrees with Hobbes on this point, and her disagreement is grounded in her divergent view of the human's essence. She believes that humans, along with every other 
individual, are comprised of inanimate matter thoroughly blended together with matter that is self-active or internally moved, as well as sensitive and rational. Accordingly, there are three types of matter for Cavendish: inanimate, animate sensitive, and animate rational, but because all three are thoroughly blended, no part of matter lacks any of these three types. Cavendish has good reasons for holding this seemingly strange view. ${ }^{10}$ For my current purposes, I simply state Cavendish's belief on this issue, in order to explain the relation between her metaphysics of matter and the question of human freedom.

Matter's self-motion permits that any material thing-a human will, for example-can be the free and undetermined source of its own movement and does not need to be causally moved by something outside of itself - a prior desire in the human brain, for example. Cavendish explains, "By voluntary actions I understand self actions; that is, such actions whose principle of motion is within themselves, and doth not proceed from such an exterior agent." "11 If something material (such as the will) is moved due to the fact that other material "parts do drive or press upon" it, then "those are forced and constraint actions; whenas [sic] natural self-motions are free and voluntary." 12 In her Philosophical Letters, she explicitly notes that human wills can be entirely free from determination by everything outside themselves (Philosophical Letters, 95 and 225), and this includes a prior state of the human mind-a thought, desire, or emotion, for example. ${ }^{13}$ The fact that the human will, like all material bodies in nature, is rational means that it can provide itself with its own reasons for acting in the way that it does. Therefore, human free will does not result in chaotic action; human actions following from our radical freedom are entirely meaningful and rational. Cavendish explicitly contrasts her position with that of Hobbes. Hobbes's materialism, according to which motion is externally imposed upon matter and is not intrinsic to matter itself, can only result in actions of matter that are extrinsically and antecedently determined, and so cannot allow freedom of the (material) will as in Cavendish's model.

Cavendish thus believes that all parts of the natural world share the same essence, namely, in being rational, sensing, and limited in their reasoning and sensing capacities. At the same time, humans are all alike-and unlike other individuals-in that we exhibit a specific, uniquely human form of rationality. ${ }^{14}$ Consequently, here is an essential human nature, which we all share by virtue of our being human, and this 
is defined in terms of human rationality. Our essential rationality is crucial in underwriting our radical freedom, which includes our freedom from both internal constraints, such as passions like fear, and external constraints, such as other individuals attempting to exercise some sort of determining influence over one's will. Relatedly, our degree of freedom from internal and external constraints will depend upon the degree to which we have developed our rationality, and upon our ability to insulate a well-developed rational capacity from the influences of our sensitive nature, including our passions. Finally, Cavendish places a strong emphasis on the preservation of the unconstrained (both internally and externally) free will-indeed, it is prescriptively good to cultivate such a will-because to manipulate a human through fear or some external constraint is to misuse her rational capacity, thus violating that aspect of her essential nature and robbing her of her fullest possible freedom (e.g., Grounds, 248-49).

Given this background on pivotal aspects of Cavendish's theory of human nature, her advocacy of female education, to develop women's natural rational capacities as essential for women's freedom, makes perfect sense. Her theoretical philosophy grounds the powerful articulation in her plays of her feminist view on women, education, and freedom. This vision alerts us to one of a number of departures from Hobbes's account of freedom-departures that allow us to see Cavendish as presenting a recognizably feminist alternative to Hobbes. Hobbes has often been portrayed as the quintessential theorist of negative liberty. That is, as Quentin Skinner puts it, "[Hobbes] is claimed ... to hold the view that an individual is unfree if and only if his doing of some particular action has been rendered impossible." ${ }^{15}$ But Skinner and others ${ }^{16}$ dissent from this characterization in numerous ways. Skinner disagrees on two fronts, but only one is key for my purposes. This reason, according to Skinner, is that many negative liberty theorists often equate the powerlessness to act with a lack of freedom. This equation does indeed hold for Hobbes when the lack of power comes about as a result of an agent's intrinsic power being thwarted in its attempt to act by an external, physical force. But the equation does not hold for Hobbes (pace typical negative liberty theorists) when the lack of power is due to an intrinsic physical (or psychological) impairment, such as in the case of a sick man unable to move from his bed (Leviathan, ch. 21, 262). So, "even if no one is rendering it impossible for an agent to act in a given way, it still does not necessarily follow for Hobbes that the agent is free to perform the action concerned. This 


\section{Hobbes and His(torical) Women}

is because ... the action in question may still be beyond the agent's powers. ... [ In this case] what is certain is that, for Hobbes, the question of whether the action is one that the agent is or is not free to perform simply does not arise." 17 Nancy Hirschmann draws attention to this feature of Hobbes's thought in a way that is enlightening for a feminist analysis of him. For, according to a Hobbesian line of thought, a woman who, for example, stays with an abusive husband due to a lack of internal power to leave (due to fear of poverty, for example) does not thereby lack the freedom to leave. ${ }^{18}$ Cavendish conversely recognizes that women may have more restrictive internalized constraints by virtue of their unique social experiences. Where there is a difference between the sorts of power or ability possessed by men (as men) and those enjoyed by women (as women), and where these differences allow for a narrower range of abilities that women can undertake, Cavendish's account of freedom can take note of these differences while Hobbes's cannot. That is, Cavendish's account is able to say that women are less free than are men, should women have less power or ability to act due to socially developed, internal constraints. So for Hobbes, one does not lack freedom should one happen to lack the power to act. For Cavendish, one does lack freedom when one lacks power, and in her plays she clearly articulates the degree to which women have less power and thus less freedom than do men for unnatural, wholly conventional reasons, due to their diminished rationality, due to their poor education.

Cavendish's view of human nature-humans are essentially rational and can enjoy radical freedom-is also the source of an important departure from Hobbes on civic freedom. While this divergence is not necessarily grounded in feminist concerns for Cavendish, it nonetheless underscores her emphasis on the importance of individual freedom, even from a sovereign's control, an emphasis that does ground her feminist vision. Given Cavendish's usual devotion to an absolute sovereignty, it would seem that she should agree with Hobbes that the sovereign determines laws which then exercise control over citizens (e.g., Leviathan, ch. 21, 263-64), binding their wills, even if through an internal constraint such as fear, and thereby aiming to prevent them from acting in the way they do in a natural state. As Hobbes famously writes, "Feare and Liberty are consistent.... And generally all actions which men doe in Commonwealths, for feare of the law, are actions, which the doers had liberty to omit" (ch. 21, 262-63). But in fact there is no such symmetry between her view and Hobbes's on civic freedom. Suppose that the sovereign did 
impose laws that exercised their power through fear, and this fear effectively directed the will. This would be a case of a lack of individual freedom for Cavendish (in contrast with Hobbes), for the will would be acting in accordance with something other than its own rational motivation. It would be forced into its actions through something that Cavendish considers external to the will itself-prior, fearful thoughts, for example. Fear and liberty are inconsistent for Cavendish. As a result, the realm of unfreedom is considerably wider for Cavendish than it is for Hobbes.

It is true that both Cavendish and Hobbes agree that the attempt to control citizens directly through laws and the fear they invoke will not always work reliably (Philosophical Letters, 47-48; Leviathan, ch. 21, 26364). But the normative lesson each draws from her or his particular account of fear and law is crucial. For Cavendish, even if it were possible for a sovereign to fully control citizens through fear, the sovereign still ought not to try to do so precisely because in trying to control human volitions through the exercise of fear, he who governs thus violates the individual's capacity for self-governance, which arises from welldeveloped rationality as free as possible from passions such as fear. Cavendish clearly stresses the moral importance of respecting human freedom (as she conceives it) even in the face of potential discord brought about by the exercise of freedom (e.g., Grounds, 248-49). From the perspective of the human's nature, Cavendish has a principled way of securing radical freedom of thought and of the will against all determinants-internal or external-that may exercise influence over thought or will, while Hobbes must admit that all thoughts are fully determined by antecedent conditions - conditions which, if changed, will alter the thoughts of the person. And so the picture suggesting that an absolute sovereign enacts laws, which bind citizens through fear to act in accordance with those laws, cannot be Cavendish's considered view of how the polity ought to be managed (supposing that it could, in fact, be thus managed): "But when governmental laws were devised by some usurping men, who were the greatest thieves and robbers, (for they robbed the rest of mankind of their natural liberties and inheritances, which is to be equal possessor of the world), these grand original thieves and robbers, which are called moral philosophers or commonwealth makers, were not only thieves and tyrants to the generality of mankind, but they were rebels against Nature, imprisoning Nature within the jail of restraint." ${ }^{19}$ Particularly interesting in this passage is Cavendish's reference to the natural state of the world, and the 
suggestion that civil laws can be a violation of nature itself-indeed, a violation, which is, in some important sense, to be avoided. I turn to this point now as crucial to another way in which we can read Cavendish as providing a feminist account of freedom as an alternative to Hobbes.

\section{The State of Nature and Civil Society}

Above, I argued that for Cavendish, our higher, rational selves will simply recognize what it is best to do without being manipulated by nonrational forces such as fear embodied in sanctions for not following civil law, and that the best thing to do, therefore, may not necessarily be to follow such law. What, then, is the source of normatively right action for Cavendish if not civil law? Answering this question alerts us to another way of seeing how Cavendish's theory of freedom offers a feminist alternative to Hobbes's theory. To show this, I now consider her view of the natural world writ large, including humanity's place within the whole of nature, focusing especially on the relations that we naturally, essentially bear to one another.

Cavendish believes that the natural world as a whole is intrinsically lawful, peaceful, and stable (Philosophical Letters, 146). This follows from the essence of matter as self-moving, sensitive, and (especially) rational. Because in its essence the world is imbued with reason, and does not consist merely of bits of matter moving and coming into contact with one another, the world is in itself governed by prescriptive laws, and not merely by descriptive laws. Nature as a whole is infinite, and so infinitely wise, and it prescribes, from the top down, norms and standards of orderly and harmonious behavior. As a result of this top-down prescribed order, all parts within nature must be understood as being naturally interrelated. That is, all parts are bound together by the various roles they play in the overarching, harmonious order..$^{20}$ Parts within the whole (human individuals, for example) can violate the peace because of their radical freedom to act against their prescribed roles, or because their finite share of reason leaves them ignorant of what the overall law requires of them (Grounds, $19-20) .{ }^{21}$ Such violations are the source of, for example, civil war. So, because of nature's thoroughgoing peaceable order, which is good, an individual acting as if it were an individual isolated from all others and bound by no overarching norms would lead to disorder in its immediate environs at least. Since this violation of norms and standards of order 
would be bad, one ought not to behave as if one were such a hyperindividualistic being, even though our freedom permits exactly this sort of disorderly behavior, which is harmful to others.

Crucial to this picture is the fact that what is violated by disorderly conduct is not artificial civil law, but rather the normative lawful order of the whole of nature. Moreover, all parts of nature-for example, humans in what Hobbes would call a state of nature-are essentially interrelated, such that our actions impact both positively and negatively others and their abilities to act toward their ends. Reason must be cultivated so that we can understand as well as possible the good, overarching order of nature, and can be motivated to maintain that order by freely adopting our proper roles. The basic law of nature, according to a Cavendishean picture, would include no right to self-defense (as it does for Hobbes) because it would not need to; rather, humans with well-developed reason would simply freely keep the peace. It is not surprising, then, that Cavendish condemns (pace Hobbes) the artificial, civil realm to the extent that it departs from nature, and that she glorifies nature itself, entreating humans to live in accordance with the peacefulness of the natural world as a whole. 22

This aspect of Cavendish's theory of freedom holds enormous promise from a feminist point of view, and, indeed, her account presages some recent sophisticated positions on freedom developed by contemporary feminists. As is clear from the above discussion, Cavendish extols the exercise of free will, even to the point of suggesting that a free will directed toward incorrect thought or action is better than one constrained to behave in the correct fashion. But, further, she extols a will that freely chooses to pursue actions conceived of in terms of how the agent relates to others, close and distant. This requires that we modulate our actions in accordance with our understanding of how they impact others, as well as how they impact the overall peace of the natural world. Cavendish's theory of freedom implicitly prescribes our being mindful of the fact that we are embedded in relations with others, that these relations make possible and impossible certain powers and abilities in ourselves and others, and that we should regulate our behavior accordingly. This requires that all individuals-men and women alike-recognize the needs and plans of others. Cavendish proves herself to be attuned to the specifically feminist potential of this approach in her belief that men have not, in fact, permitted women to develop themselves but have routinely "usurped" power for themselves, leaving women in "slavish" condition. ${ }^{23}$ Similarly, and more 
forcefully, this point is driven home by her characterization of women's relations with men and with other women in the plays discussed above.

It is important to underscore how remarkably modern, from a feminist perspective, this aspect of Cavendish's theory of freedom or autonomy is-for in presenting it, she anticipates an approach to autonomy we see extolled by some feminists today. Lately, a number of feminist theorists, including Marilyn Friedman, Nancy Hirschmann, Diana Tietjens Meyers, and Natalie Stoljar, ${ }^{24}$ to name a few, have argued forcefully that we should recognize the critical importance of freedom for feminist ends. Without women and men being free or autonomous agents, it is unclear how we can engage in the project of pushing against and overcoming oppression of women. Yet these theorists are still mindful of the important feminist criticisms levied against the ideal of hyperindividualistic autonomy that arguably grounds Hobbes's own theory. And so, recent theorists suggest that we "refigure" the concept of the autonomous or free individual. Central to one such refiguring is the acknowledgment that we simply do find ourselves in social relations, and that these relations are crucial to how we understand our freedom because of the range of human actions that our relations can permit or disallow. The kind and quality of our relations are important in understanding freedom or autonomy, according to these thinkers, insofar as agents are "intrinsically relational because their identities or self-conceptions are constituted by elements of the social context in which they are embedded," and insofar as social relations shape the range of options open to people. ${ }^{25}$ Taking into account our relations with others allows us to take into account the different ways in which men and women have been socialized, such that men and women often have very different intrinsic abilities and very different ranges of options open to them. This feminist account of freedom or autonomy-dubbed "relational autonomy" by many-"reflects a sense of self . . . as both differentiated from and related to others, and a sense of others as subjects with whom one shares enough to allow for a recognition of their independent interests and feelings-in short for a recognition of them as subjects."26

Cavendish's general approach to freedom holds the promise of being strikingly in stride with recent relational autonomy theorists on some points at least. Her stress on rationality over emotions, however, might make her seem less in tune with contemporary feminists. Yet she believes that to be deprived of the capacity to act from a rationally governed will-even to act in a way that is socially detrimental-is to be deprived 
of a capacity that is essential to our freedom, as it is crucial to our resisting negative influences that might rob us of the power to act. But she also clearly wants to acknowledge the importance of our being mindful of our relations with other individuals, including our social relations with our fellow humans. Rationality is crucial to both features of her theory of freedom. The more rational the will, the freer it will be from the determining influence of the passions or other individuals who might influence one to act against one's own rationally determined course of action. Moreover, better-developed rationality will allow one to better apprehend the proper peaceable order that ought to attain among all individuals; that is, better-developed rationality will allow one to better apprehend how one ought to modulate one's own free behavior in order to sensitively respect the rationally based subjectivity of one's fellows. Because this is a self-modulation or self-determination, based in one's rational comprehension of her natural and social interrelations, one who acts thus is free. Once again, the message brought home by Cavendish's plays stresses the fact that she strongly presages many themes in contemporary relational autonomy theory. Her anticipation of such themes also grounds yet more points of divergence from Hobbes. Recent feminist readings of Hobbes offer numerous ways of thinking about Hobbes's state of nature and his understanding of the transition from a state of nature to civil society; but on any of these readings of the state of nature, Cavendish's philosophy as presented above offers a more promising alternative.

On one reading of Hobbes's state of nature, isolated individuals act independently of one another to maximize their power and chances of survival. This hyperindividualism would certainly provide fodder for a feminist critique to the extent that feminism takes specific issue with the view of the human as isolated from others. Still, such a critique could be defused by recognizing Hobbes's own belief that, in a state of nature, women can be victors no less than can men (Leviathan, ch. 21, 253). Cavendish's own relational account of humans, which would presumably hold in a Hobbesian state of nature given that the natural world is the source of such relations, offers a feminist critique against any version of this hyperindividualism, regardless of whether women or men are the victors. For Cavendish, one ought not to behave in a hyperindividualistic fashion at all, most especially not to vanquish one's fellows, for this would be a violation of their essential freedom.

A second way of reading the state of nature arises because Hobbes acknowledges the human's natural tendency to seek human relation, ${ }^{27}$ 
thus calling into question the interpretation that humans are naturally atomistic individuals. Drawing on such texts, Gordon Schochet has therefore argued against the hyperindividualistic reading of humans in a state of nature and in favor of a more relational reading of the state of nature. Nonetheless, Schochet's reading resurrects feminist concerns, for he believes that the relational unit in the state of nature is patriarchal families, in which the authoritarian power of the patriarch both provides the family with stability and provides the model for the authoritarian sovereign. ${ }^{28}$ Once again, Cavendish's very different relational account based on equal human rationality and equal right to freedom offers a heartening feminist alternative to the state of nature in this interpretation.

Hirschmann offers yet a third interpretation of the state of nature as well as an interpretation of what, according to Hobbes, must happen in the transition to civil society precisely because of the relations that hold in nature. To set the backdrop for Hirschmann's interpretation, consider Hobbes's contrast between natural liberty and the liberty of subjects:

But as men, for the atteyning of peace, and conservation of themselves thereby, have made an Artificiall Man, which we call a Common-wealth; so also have they made Artificall Chains, called Civill Lawes, which they themselves, by mutuall covenants, have fastned at one end, to the lips of that Man, or Assembly, to whom they have given the Soveraigne Power; and at the other end to their own Ears. These Bonds in their own nature but weak, may neverthelesse be made to hold, by the danger, though not by the difficulty of breaking them. In relation to these Bonds only it is, that I am to speak now, of the Liberty of Subjects. (Leviathan, ch. 21, 263-64)

Civil laws act as "a coercive Power to tye their [men's] hands from rapine, and revenge" (Leviathan, ch. 18, 238; cf. ch. 30, 388, and ch. 46, 701). The actions of a subject in a civil society are constrained by what seem to be external impediments, namely laws, and so the subject in civil society would seem to lack freedom to the degree that civil laws keep one from acting in accordance with the determination of his own will. Relatedly, Hobbes contrasts the state of nature, where there is "a full and absolute Libertie in every Particular man" (ch. 21, 266), with civil society, where "Civill Law is an Obligation; and takes from us the Liberty which the Law of Nature gave us" (ch. 27, 334-35; cf. ch. 14, 189). In 
order to reconcile Hobbes's account of freedom in a state of nature with his account of freedom in civil society, Hirschmann offers the following interpretation:

Consent is the only way to preserve ... natural freedom. In a social contract, all agree to alienate certain of their liberties to a sovereign who will in turn oversee everyone's behavior. What makes this legitimate is that people choose to enter into this contract; the limitation of their liberty that the contract imposes is thus also an expression of their liberty-even, perhaps, its ultimate expression.... [But] we are compelled to consent to the social contract because we have no practical choice in the matter; it is the only choice we can rationally make. ${ }^{29}$

While freedom is that which brings about the social contract on this reading, freedom "is not an end in itself, but rather a means to other things that are of greater importance, such as security." ${ }^{130}$ Moreover, since for Hobbes fear is not always adequate to compel consent, he turns to mechanisms such as education "to guide and shape people's desires" such that they will consent to the social contract. ${ }^{31}$ Hirschmann further develops the argument that women's desires must be shaped very differently from men's in order to maintain patriarchal families in civil society, which provide the model for authoritarian governments. ${ }^{32}$ Key to this last point is Hirschmann's belief (pace Schochet as characterized above) that women in a state of nature are not under men's power in patriarchal families, are thus a threat to men, and so need to be shaped to take on their proper role in the patriarchal family in civil society (rather than in a state of nature). Hirschmann's interpretation of Hobbes's state of nature thus maintains that humans are indeed in relations, but that these are instrumental relations entered into only insofar as they increase our natural power over potential threats (e.g., children are useful to women in helping them maintain their power over men); $;^{33}$ they are not relations based primarily on nurture and care. Assuming this third interpretation of the state of nature, women need to be shaped through, for example, education to freely consent to their subordinate status in civil society for the sake of social stability.

Once again, Cavendish's understanding of productive human relations would not tolerate instrumental relations as we find in Hobbes on this third interpretation of his state of nature. Cavendish's theory requires 
that we acknowledge the rationality, and the freedom from internal and external constraints, proper to each human as subject. Such relations require seeing others as subjects with projects of their own, and not as instruments for one's own use. Finally, while education for Hobbes according to Hirschmann's interpretation must shape individuals to take on very specific and gendered social roles, Cavendish holds that women need to be educated to their full natural potential in order to be relieved of the submission in which they find themselves. This will allow women to understand clearly the ways in which they can naturally, equally with men, and productively contribute to the order and stability that follow from what is central, crucial, and never to be compromised: human freedom to act from well-developed abilities and powers, mindful of others and their freedoms.

Still, at least one commentator, Sharon Lloyd, believes that Hobbes's educational theory is not a form of indoctrination or "objectionable intellectual coercion," ${ }^{34}$ but rather is meant to lead citizens to a state of rational self-governance. For the sake of argument, let me suppose that this is an accurate interpretation of Hobbes's educational theory. His theory would still compare negatively to Cavendish's theory of education from a feminist point of view. For Hobbes's drive to have citizens welleducated (granting the belief that he endorses true education, not indoctrination) is a drive to educate citizens, not individuals considered in and of themselves. His aim with education is to achieve stability of a certain type of polity, with the benefit that will accrue to individuals (peaceful coexistence, for example) following derivatively upon this. This is in contrast with Cavendish's primary aim, which is to develop the capacities and abilities of individuals to their fullest. But, on Hobbes's view, education will therefore teach people to take on whatever social roles are necessary for the stability and longevity of the polity, and this opens up the threat, as Hirschmann notes, that men and women will be differentially educated to take on different, gendered roles. Differential education for men and women is blocked in principle on Cavendish's account, while it is not blocked in principle on Hobbes's account.

Regardless of which interpretation of Hobbes's state of nature is favored, Cavendish presents a promising feminist alternative to any of them in presaging the relational autonomy, grounded in the natural equality of men and women, that we find in contemporary philosophy. And she offers a theory of education in the social-civic world that promotes human rationality and freedom, both for the human's own sake and so 
that she or he can better understand how to enter into productive, caring, and equal relations with other humans, no matter their gender. These points, together with her recognition that women may have greater internal constraints due to their having been so socialized, and that these constraints represent a state of lesser freedom, indicate that Cavendish offers a refreshingly feminist alternative to Hobbes's theory of freedom.

\section{Notes}

1. On Cavendish's materialism and the argument for it, see, for example, Margaret Cavendish, Observations upon Experimental Philosophy, 2nd ed., ed. Eileen O'Neill (Cambridge: Cambridge University Press, 2001), 137. On Hobbes's materialism and a similar argument for it, see, for example, Thomas Hobbes, Leviathan, ed. C. B. Macpherson (New York: Penguin, 1985), ch. 34, 428-29. Subsequent references are given in the text by chapter and page number.

2. See, for example, Thomas Hobbes, The English Works of Thomas Hobbes of Malmesbury, ed. Sir William Molesworth, 11 vols. (London: J. Bohn, 1839-45), 1:412; Cavendish, Observations (2001 ed.), 17; and Margaret Cavendish, Philosophical Letters, or Modest Reflections upon Some Opinions in Natural Philosophy (London, 1664), 139, 142. Subsequent references to Philosophical Letters are given in the text. For complications associated with this view of Cavendish, see Karen Detlefsen, "Margaret Cavendish on the Relation Between God and World," Philosophy Compass 4, no. 3 (2009): 421-38.

3. See, for example, Margaret Cavendish, "An Epistle to the Reader," in Philosophical and Physical Opinions, 2nd ed. (London: William Wilson, 1663); Margaret Cavendish, "Birth, Breeding, and Life of Margaret, Duchess of Newcastle," in The Life of William Cavendish, Duke of Newcastle, ed. C. H. Firth, 2nd ed. (London: George Routledge and Sons, 1906), 157-58 and 175; Margaret Cavendish, Orations of a Divers Sort, in Political Writings, ed. Susan James (Cambridge: Cambridge University Press, 2003), 118 and 249; and Margaret Cavendish, "Preface to the Reader," in The World's Olio (London: printed for J. Martin and J. Allestree, 1655).

4. See, for example, Cavendish, Philosophical Letters, 47-48.

5. Margaret Cavendish, Playes (London: A. Warren, 1662), 653. Subsequent references are given in the text.

6. Margaret Cavendish, The Convent of Pleasure and Other Plays, ed. Anne Shaver (Baltimore: Johns Hopkins University Press, 1999), 227. Subsequent references are given in the text.

7. Thanks to Joanne Wright for drawing my attention to the purpose of seventeenth-century convents.

8. Hobbes, English Works, 5:34.

9. Here, she cites Hobbes's Leviathan, ch. 6, 127-28.

10. For an account of why Cavendish would hold such a peculiar view of the natural world, see Karen Detlefsen, "Reason and Freedom: Margaret Cavendish on the Order and Disorder of Nature," Archiv für Geschichte der Philosophie 89, no. 2 (2007): 157-89.

11. Cavendish, Observations (2001 ed.), 19.

12. Ibid., 127.

13. Margaret Cavendish, Observations upon Experimental Philosophy (London: A. Maxwell, 1666), $49,54-55$.

14. See, for example, Margaret Cavendish, Grounds of Natural Philosophy (London: A. Maxwell, 1668; facsimile repr., West Cornwall, Conn.: Locust Hill Press, 1996), 15. Subsequent references are given in the text. 


\section{Hobbes and His(torical) Women}

15. Quentin Skinner, "Thomas Hobbes on the Proper Signification of Liberty: The Prothero Lecture," Transactions of the Royal Historical Society, 5th ser., 40 (1990): 127.

16. Including Nancy ]. Hirschmann in her recognition that there are elements of positive liberty to be found in Hobbes. See Hirschmann, Gender, Class, and Freedom in Modern Political Theory (Princeton, N.J.: Princeton University Press, 2008), 63-70.

17. Skinner, "Thomas Hobbes," 127-28; emphasis added.

18. Hirschmann, Gender, 35.

19. Cavendish, Orations, 176.

20. For an account of this feature in Cavendish, including its broader implications in her philosophy, see Karen Detlefsen, "Atomism, Monism, and Causation in the Natural Philosophy of Margaret Cavendish," Oxford Studies in Early Modern Philosophy, ed. Steven Nadler and Daniel Garber, vol. 3 (Oxford: Oxford University Press, 2006), 199-240.

21. For a development of this, see Detlefsen, "Relation."

22. See, for example, Cavendish, Observations (1666 ed.), 4.

23. Cavendish, "Preface to the Reader."

24. For example, see papers in Catriona Mackenzie and Natalie Stoljar, eds., Relational Autonomy: Feminist Perspectives on Autonomy, Agency, and the Social Self (New York: Oxford University Press, 2000).

25. Mackenzie and Stoljar, introduction to Relational Autonomy, 22.

26. Evelyn Fox Keller, Reflections on Gender and Science (New Haven, Conn.: Yale University Press, 1985), 99.

27. See, for example, Thomas Hobbes, De Cive, in Man and Citizen: Thomas Hobbes's "De Homine" and "De Cive," ed. Bernard Gert (Garden City, N.Y.: Anchor Books, 1972), 1.2.

28. Gordon J. Schochet, The Authoritarian Family and Political Attitudes in Seventeenth-Century England: Patriarchalism in Political Thought (New Brunswick: Transaction Books, 1988), 225-43. See also Schochet's "Thomas Hobbes on the Family and the State of Nature" in chapter 5 of this volume.

29. Hirschmann, Gender, 39-40.

30. Ibid., 62.

31. Ibid., 78. This social construction of the individual is the basis of Hirschmann's attributing elements of positive liberty to Hobbes, as mentioned above in note 16.

32. Ibid., 72-74.

33. Ibid., 54-57.

34. S. A. Lloyd, "Coercion, Ideology, and Education in Hobbes's Leviathan," in Reclaiming the History of Ethics: Essays for John Rawls, ed. Andrews Reath, Barbara Herman, and Christine M. Korsgaard (Cambridge: Cambridge University Press, 1996), 36-65. Cf. S. A. Lloyd, Ideals as Interests in Hobbes's "Leviathan": The Power of Mind over Matter (Cambridge: Cambridge University Press, 1992), 159-66. 